\title{
Spatio-Temporal Emissions of Ammonia and Greenhouse Gases from Livestock and Its Relation to Atmospheric Particulate Matter Pollution in the Beijing-Tianjin-Hebei Region
}

\author{
Yixuan Guo ${ }^{1,2}$, Shufeng Chen ${ }^{3 *}$, Changcheng Guo ${ }^{1}$, Yuntao Shang ${ }^{1}$, \\ Zhigang Zhang ${ }^{1}$, Yidong Wang ${ }^{1,2}$
}

\begin{abstract}
${ }^{1}$ Tianjin Key Laboratory of Water Resources and Environment, Tianjin Normal University, Tianjin 300387, China ${ }^{2}$ School of Geographic and Environmental Sciences, Tianjin Normal University, Tianjin 300387, China ${ }^{3}$ Beijing Municipal Research Institute of Environmental Protection, Beijing 100037, China
\end{abstract}

Received: 5 May 2021

Accepted: 27 July 2021

\begin{abstract}
Livestock farming sector is an important anthropogenic emission source of ammonia $\left(\mathrm{NH}_{3}\right)$ and greenhouse gases including nitrous oxide $\left(\mathrm{N}_{2} \mathrm{O}\right)$ and methane $\left(\mathrm{CH}_{4}\right)$. The $\mathrm{NH}_{3}$, not $\mathrm{N}_{2} \mathrm{O}$ and $\mathrm{CH}_{4}$, is known as an important gaseous precursor to cause atmospheric particulate matter (PM) pollution. However, the relationship between livestock-derived $\mathrm{NH}_{3}$ and atmospheric $\mathrm{PM}$ pollution has not been sufficiently investigated, especially in the developed regions with serious air pollution. Here, we studied the spatio-temporal emissions of $\mathrm{NH}_{3}, \mathrm{~N}_{2} \mathrm{O}$ and $\mathrm{CH}_{4}$ from livestock farming as well as the relationship between livestock $\mathrm{NH}_{3}$ emission and atmospheric PM pollution in the Beijing-Tianjin-Hebei Region, one of the most developed and air polluted area in China. Over the past 40 years, livestock-derived emissions of $\mathrm{NH}_{3}, \mathrm{~N}_{2} \mathrm{O}$ and $\mathrm{CH}_{4}$ had experienced four temporal stages (1978-1990: low level; 1991-1995: rapid growth; 1996-2005: reached hot moments; 2006-2018: stable at a high level). Livestock-derived emissions of $\mathrm{NH}_{3}, \mathrm{~N}_{2} \mathrm{O}$ and $\mathrm{CH}_{4}$ were 813, 19 and $499 \mathrm{Gg}$ in 2017, respectively. The southeastern plain was the hotspot, and the pig and cattle were the main sources (78-99\%) of $\mathrm{NH}_{3}, \mathrm{~N}_{2} \mathrm{O}$ and $\mathrm{CH}_{4}$ in livestock farming. The livestock-derived $\mathrm{NH}_{3}$ emission explained approximately a quarter of the variations of atmospheric $\mathrm{PM}_{2.5}$ (size $\left.\leq 2.5 \mu \mathrm{m}\right)(24 \%)$ and $\mathrm{PM}_{10}$ (size $\left.\leq 10 \mu \mathrm{m}\right)(22 \%)$ pollution. Based on the knowledge of atmospheric chemical processes, we concluded that the livestock-derived $\mathrm{NH}_{3}$ emission significantly affected atmospheric $\mathrm{PM}_{2.5}$ and $\mathrm{PM}_{10}$ pollution in the Beijing-Tianjin-Hebei Region. Consequently, the livestock farming, especially pig and cattle breeding, should be paid more attention
\end{abstract}

*e-mail: shufengchen@163.com 
in the context of atmospheric particulate matter pollution and regional greenhouse gases management.

Keywords: ammonia $\left(\mathrm{NH}_{3}\right)$, greenhouse gases $(\mathrm{GHGs})$, methane $\left(\mathrm{CH}_{4}\right)$, nitrous oxide $\left(\mathrm{N}_{2} \mathrm{O}\right), \mathrm{PM}_{2.5}$

\section{Introduction}

Livestock farming sector is one of the main anthropogenic emission sources of ammonia $\left(\mathrm{NH}_{3}\right)$ and greenhouse gases (GHGs) including nitrous oxide $\left(\mathrm{N}_{2} \mathrm{O}\right)$ and methane $\left(\mathrm{CH}_{4}\right)$ [1-4]. Among the three gases, $\mathrm{NH}_{3}$, as an important gaseous precursor of inorganic aerosol, plays an important role in atmospheric particulate matter formation [5-7]. For example, $\mathrm{NH}_{3}$ can react with sulfur dioxide $\left(\mathrm{SO}_{2}\right)$, nitrogen oxides $\left(\mathrm{NO}_{\mathrm{X}}\right)$, etc. to produce secondary particles and aerosols such as ammonium sulfate $\left(\left(\mathrm{NH}_{4}\right)_{2} \mathrm{SO}_{4}\right)$, ammonium sulfite $\left(\mathrm{H}_{8} \mathrm{~N}_{2} \mathrm{O}_{3} \mathrm{~S}\right)$ and ammonium nitrate $\left(\mathrm{NH}_{4} \mathrm{NO}_{3}\right)$ [8-9]. In contrast, $\mathrm{N}_{2} \mathrm{O}$ and $\mathrm{CH}_{4}$ persist in the atmosphere for a relatively long time [10] and have little role in the formation of surface atmospheric particulate matter [6, 11]. Although $\mathrm{N}_{2} \mathrm{O}$ can produce $\mathrm{NO}_{2}$ (an important air particulate pollutant), this reaction mainly occurs in the stratosphere [10]. Therefore, it is of importance to understand the spatio-temporal emissions of livestockderived $\mathrm{NH}_{3}, \mathrm{~N}_{2} \mathrm{O}$ and $\mathrm{CH}_{4}$ as well as the relationships between $\mathrm{NH}_{3}$ and atmospheric particulate matter pollution in the context of atmospheric pollution and global climate change [12-14].

At a global scale, livestock farming as well as itsinduced land use changes contributed 64\%, 65\% and $37 \%$ of anthropogenic $\mathrm{NH}_{3}, \mathrm{~N}_{2} \mathrm{O}$ and $\mathrm{CH}_{4}$ emissions, respectively [15]. The hotspots were in Asia, especially in India and China over recent decades [16-17]. The emissions of $\mathrm{NH}_{3}$ and GHGs from China's animal husbandry showed an upward trend, with an average annual growth rate of $2.2 \%$ [18-19]. Even though there are some studies on livestock-derived $\mathrm{NH}_{3}$ and GHGs emissions in several regions in China [20-22], the spatio-temporal patterns of the very developed and air polluted areas has not been sufficiently studied. Moreover, the impact of livestock-derived $\mathrm{NH}_{3}$ emission on regional atmospheric particulate matter pollution is a hot research topic [23]. The current researches mainly focus on the three aspects of small region [24], facility farming [25-27] and atmospheric particulate matter formation mechanism [12]. On a regional scale, however, the spatio-temporal emissions of $\mathrm{NH}_{3}$, $\mathrm{N}_{2} \mathrm{O}$ and $\mathrm{CH}_{4}$ from livestock farming as well as the relationships between $\mathrm{NH}_{3}$ and atmospheric particulate matter pollution have not been sufficiently investigated.

The Beijing-Tianjin-Hebei region is one very developed and air polluted (especially particulate matter) areas in China [28]. In the global context of low-carbon economy, the Beijing-Tianjin-Hebei region is facing the double pressure of rapid economic \& social development and reduction in $\mathrm{NH}_{3}$ and GHGs emissions. The Beijing-Tianjin-Hebei region has intense livestock farming, however, how it affects spatio-temporal emissions of $\mathrm{NH}_{3}, \mathrm{~N}_{2} \mathrm{O}$ and $\mathrm{CH}_{4}$ and the surface atmospheric particulate matter pollution is unclear. The objective of this study was to (i) investigate the spatiotemporal emissions of $\mathrm{NH}_{3}$ and GHGs from livestock farming as well as its dominant sources, and (ii) explore the correlation between livestock-derived $\mathrm{NH}_{3}$ emission and surface atmospheric particulate matter pollution in the Beijing-Tianjin-Hebei region.

\section{Materials and Methods}

\section{Study Site}

This study was conducted in the Beijing-TianjinHebei (B-T-H) region $\left(113^{\circ} 27^{\prime}-119^{\circ} 50^{\prime} \mathrm{E}, 36^{\circ} 05^{\prime}-42^{\circ} 40^{\prime} \mathrm{N}\right)$ in China, with a total area of $218,000 \mathrm{~km}^{2}$. The B-T-H region gradually transitions from the northwest Yanshan-Taihang Mountain to the Southeast Plain. The mountain and plain accounted for $53.7 \%$ and $46.3 \%$ of the whole B-T-H region, respectively. The northwest mountain and southeast plain were characterized by a temperate continental climate and a warm temperate monsoon climate, respectively. There are four distinct seasons in this area, with the same period of rainfall and heat. The annual precipitation is approximately $300-800 \mathrm{~mm}$, and the mean annual temperatures are $0-13^{\circ} \mathrm{C}$ in the $\mathrm{B}-\mathrm{T}-\mathrm{H}$ region. The regional soil types are mainly Burozem, Cinnamon Soil, Calcaric Cambisol and Chestnut Soil [3].

The B-T-H region has two megalopolis (Beijing and Tianjin Municipalities) and 11 prefecture level cities of the Hebei Province, which is one developed area in China. By the end of 2018, the B-T-H had a permanent population of 113 million, with a population density of 517 people $\mathrm{km}^{-2}$. The total gross domestic product of the $\mathrm{B}-\mathrm{T}-\mathrm{H}$ region was 8.5 trillion $\mathrm{RMB}$, and the number of motor vehicles was approximately 24.6 million. The area of cropland was the largest, accounting for $34.8 \%$ of the whole area of B-T-H region. The forest land, grassland, construction land, water area and unused land accounted for $22.3 \%, 14.0 \%, 12.1 \%, 2.9 \%$ and $0.69 \%$ of the total area, respectively.

\section{Data Collection of Livestock Farming}

The livestock farming of the B-T-H region mainly includes five types: dairy cattle, meat cattle, pigs, broilers and laying hen. The long-term (1978-2018) data of the livestock farming were collected based on the official statistical yearbook of Beijing Statistics Yearbook 2003-2019 (data of 1978-2018), District 
Statistical Yearbook of Beijing 2008-2019 (data of 2007-2018), Tianjin Statistical Yearbook 2002-2018 (data of 2000-2018), Hebei Economic Yearbook 2008-2018 (data of 1978-2017, the data of prefecture level cities were only during 2008-2017) and previous published articles [20, 29]. The annual breeding quantity of livestock was calculated as follows. If the breeding cycle was less than 1 year, the slaughtering amount was taken as the current year's breeding quantity, such as pigs, beef cattle and broilers. If the breeding period exceeded 1 year, the year-end stocks were the current farming amount, such as laying hens and dairy cattle [30].

Furthermore, a high-resolution spatio-temporal survey on the livestock farming in Beijing Municipality was conducted only during 2010-2014 [30]. The highresolution spatial datasets were obtained by intensive field inventory survey of almost all livestock farming enterprises (including dairy cattle, meat cattle, pigs, broilers and laying hens) in the entire Beijing Municipality [30]. Our survey projects involved the number of annual reproduction (head), farming cycle, output amount, agricultural utilization and sewage treatment methods.

\section{Estimation of Livestock-Derived $\mathrm{NH}_{3}, \mathrm{~N}_{2} \mathrm{O}$ and $\mathrm{CH}_{4}$ Emissions}

The livestock-derived emissions of $\mathrm{NH}_{3}, \mathrm{~N}_{2} \mathrm{O}$ and $\mathrm{CH}_{4}$ in the B-T-H region were estimated based on the emission factor method. The total emissions of $\mathrm{NH}_{3}$, $\mathrm{N}_{2} \mathrm{O}$ and $\mathrm{CH}_{4}$ in the B-T-H region were calculated by adding the emissions of all kinds of livestock in different years using the Equation (1) and Equation (2):

$$
\begin{gathered}
E_{i}=A_{i} \times E F_{i} \\
\mathrm{E}=\sum_{i}\left(A_{i} \times E F_{i}\right)
\end{gathered}
$$

where $E_{i}$ is the emission of each livestock type $(\mathrm{Gg})$; $A_{i}$ is the annual breeding quantity of each livestock type (head); $E F_{i}$ is the emission factor of each livestock type $\left(\mathrm{kg} \mathrm{head}^{-1} \mathrm{yr}^{-1}\right), E$ is the total emission of $\mathrm{NH}_{3}$, $\mathrm{N}_{2} \mathrm{O}$ and $\mathrm{CH}_{4}(\mathrm{Gg})$.
The $\mathrm{NH}_{3}$ emission factors of the livestock farming were based on published literature [31-32]. Different management stages of livestock farming are considered, such as captive farming, fecal storage, returning to field application and grazing [21]. The $\mathrm{N}_{2} \mathrm{O}$ and $\mathrm{CH}_{4}$ emission factors are based on the emission factors for enteric fermentation and manure management of different livestock under different feeding methods given in the "Guidelines for the preparation of provincial greenhouse gas inventories" (No. [2011]1041) issued by China. All the emission factors are shown in Table 1.

\section{Data Collection of Atmospheric Particulate Matter Concentration}

The annual mean atmospheric particulate matter $\left(\mathrm{PM}_{2.5}\right.$ and $\mathrm{PM}_{10}$, size $\leq 2.5 \mu \mathrm{m}$ and $\leq 10 \mu \mathrm{m}$, respectively) concentrations in the B-T-H region were all from the official website data bulletin of Beijing Environmental Statement (data of 2000-2018), Tianjin Ecology and Environment Statement (data of 2002-2018) and Hebei Province Ecology and Environment Condition Statement (data of 1998-2018).

\section{Data Analysis}

The temporal emissions of $\mathrm{NH}_{3}$ and GHGs from livestock farming were shown using Origin 9.0 (OriginLab Corporation, Northampton, MA). The spatial emissions of $\mathrm{NH}_{3}$ and GHGs from livestock farming were analyzed by Global Positioning System (GPS) and Geographic Information System (GIS) 10.2 (ArcMap, ESRI, MA). The linear relationship between the emission of $\mathrm{NH}_{3}$ and atmospheric particulate matter $\left(\mathrm{PM}_{2.5}\right.$ and $\left.\mathrm{PM}_{10}\right)$ content was analyzed by SPSS 17.0.

\section{Results}

\section{Spatio-Temporal Patterns of Livestock Farming}

Over the past 40 years (1978-2018), the breeding structure of the five livestock farming types in the B-T-H region changed not much on this long time scale (Fig. 1). In the B-T-H region, the proportion of cattle and pigs breeding were relatively stable and reached

Table 1. The emission factors of the livestock farming $\left(\mathrm{kg} \mathrm{head}^{-1} \mathrm{yr}^{-1}\right)$.

\begin{tabular}{|c|c|c|c|c|}
\hline \multirow{2}{*}{ Livestock } & \multirow{2}{*}{$\mathrm{NH}_{3}$} & $\mathrm{~N}_{2} \mathrm{O}$ & \multicolumn{2}{|c|}{$\mathrm{CH}_{4}$} \\
\cline { 3 - 5 } & 37.61 & 1.846 & Enteric fermentation & Fecal management \\
\hline Dairy cattle & 22.58 & 0.794 & 88.1 & 7.46 \\
\hline Meat cattle & 11.55 & 0.227 & 1 & 2.82 \\
\hline Pigs & 0.18 & 0.007 & - & 3.12 \\
\hline Broilers & 0.61 & 0.007 & - & 0.01 \\
\hline Laying hen & & & & 0.01 \\
\hline
\end{tabular}



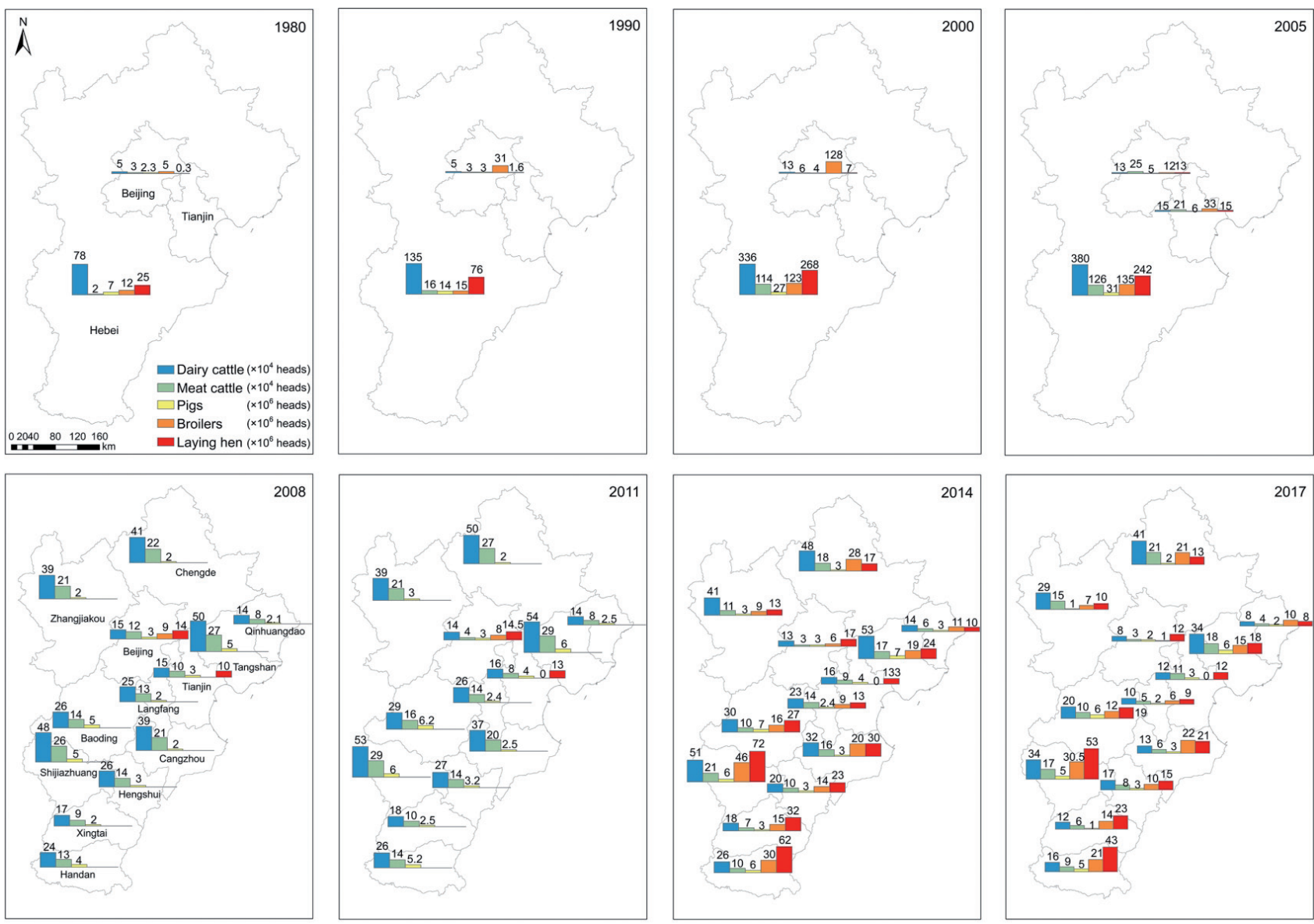

Fig. 1. The breeding amount of the five livestock types in the Beijing-Tianjin-Hebei region.

the peak in 2005 and 2014, respectively. In contrast, the production of pigs and broilers in Beijing reached its peak in 2003 and then declined slowly; and laying hens peaked in 2014 (Fig. 1).

The livestock farming enterprises were mainly distributed in suburbs of Beijing during 2010-2014 (Fig. 2). The number and distribution of livestock farming enterprises in Beijing changed little in the past 5 years. The southeast plain was dominated by dairy cattle, meat cattle, pigs and laying hens. Broilers were mostly distributed in the northwest mountainous area (Fig. 2). During 2010-2014, the breeding quantity of pigs and laying hens increased slowly, while the rest showed a downward trend (Fig. 2). The number of dairy cattle, meat cattle and broilers in 2014 decreased by $8.8 \%$, $40.4 \%$ and $46.8 \%$ compared with 2010 , respectively. On the contrary, the number of pigs and laying hens increased by $1.5 \%$ and $60.1 \%$ respectively. In addition,
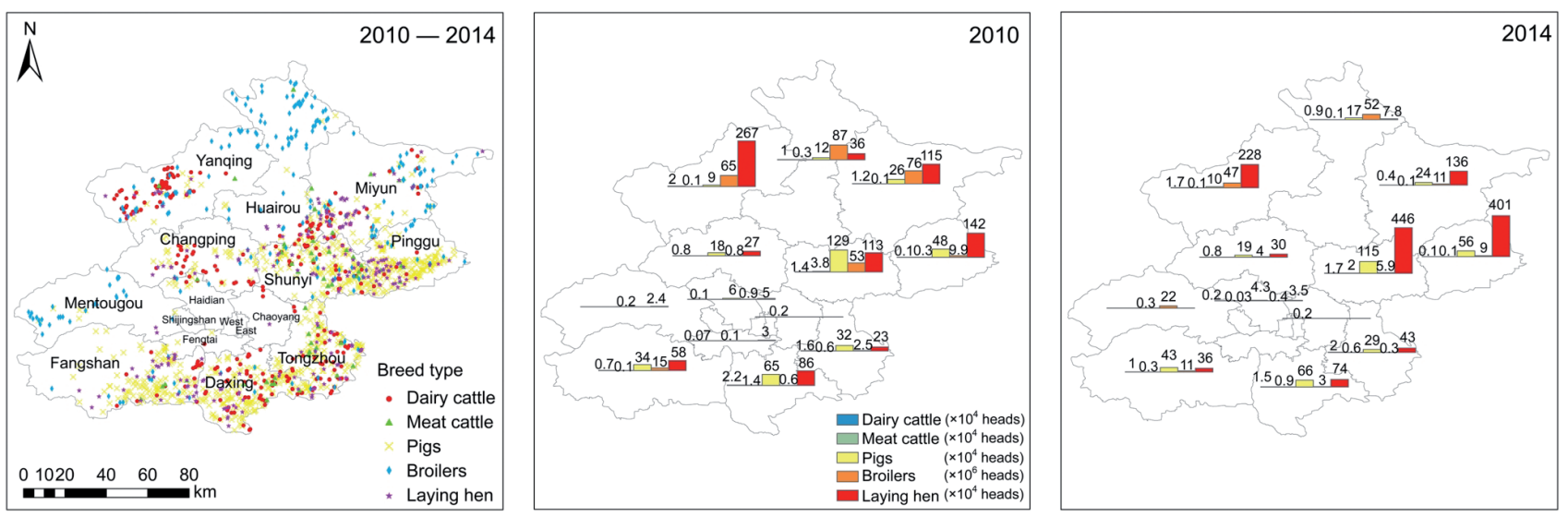

Fig. 2. Distribution of livestock farming enterprises and breeding amounts of the five livestock types in the Beijing Municipality during 2010-2014. 


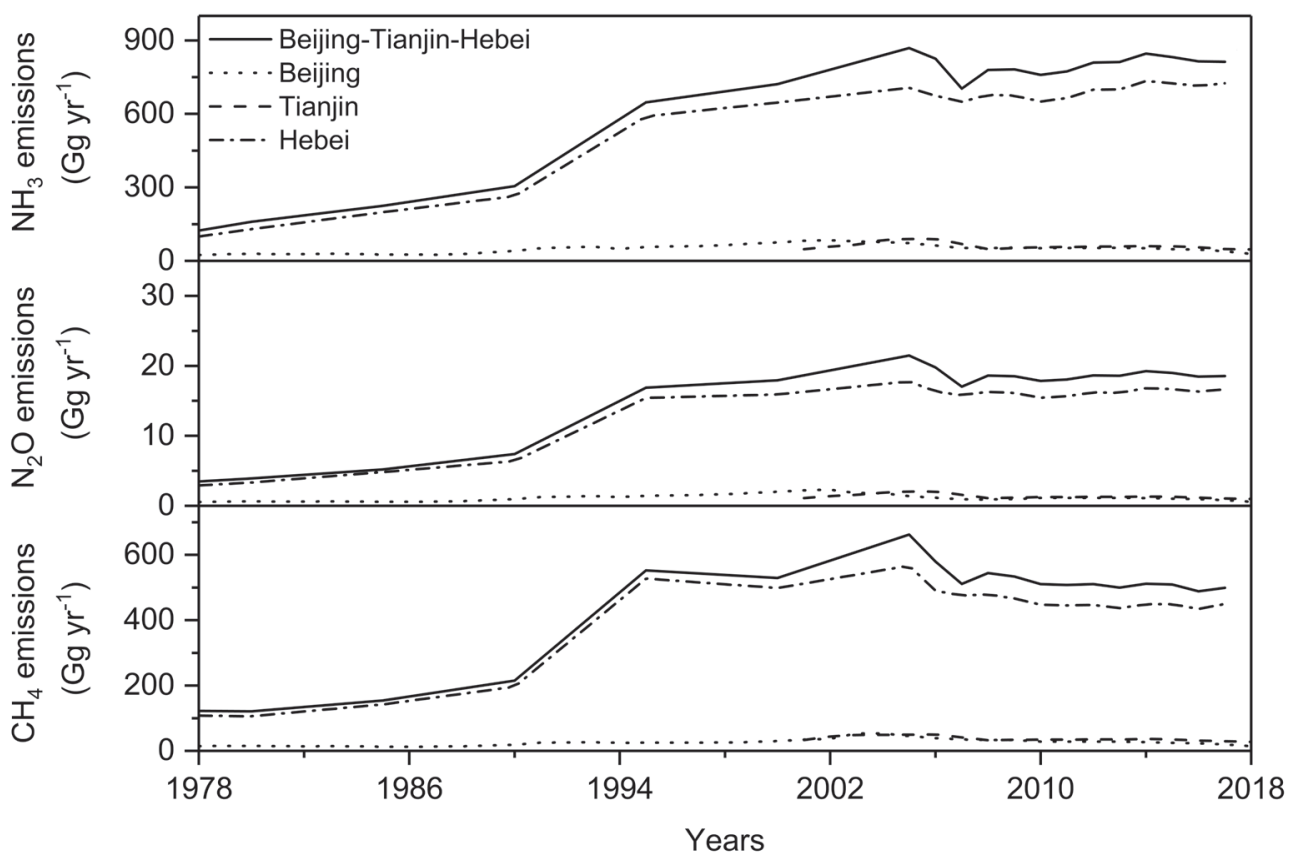

Fig. 3. Temporal emissions of $\mathrm{NH}_{3}, \mathrm{~N}_{2} \mathrm{O}$ and $\mathrm{CH}_{4}$ from the livestock farming in the Beijing-Tianjin-Hebei region during $1978-2018$.
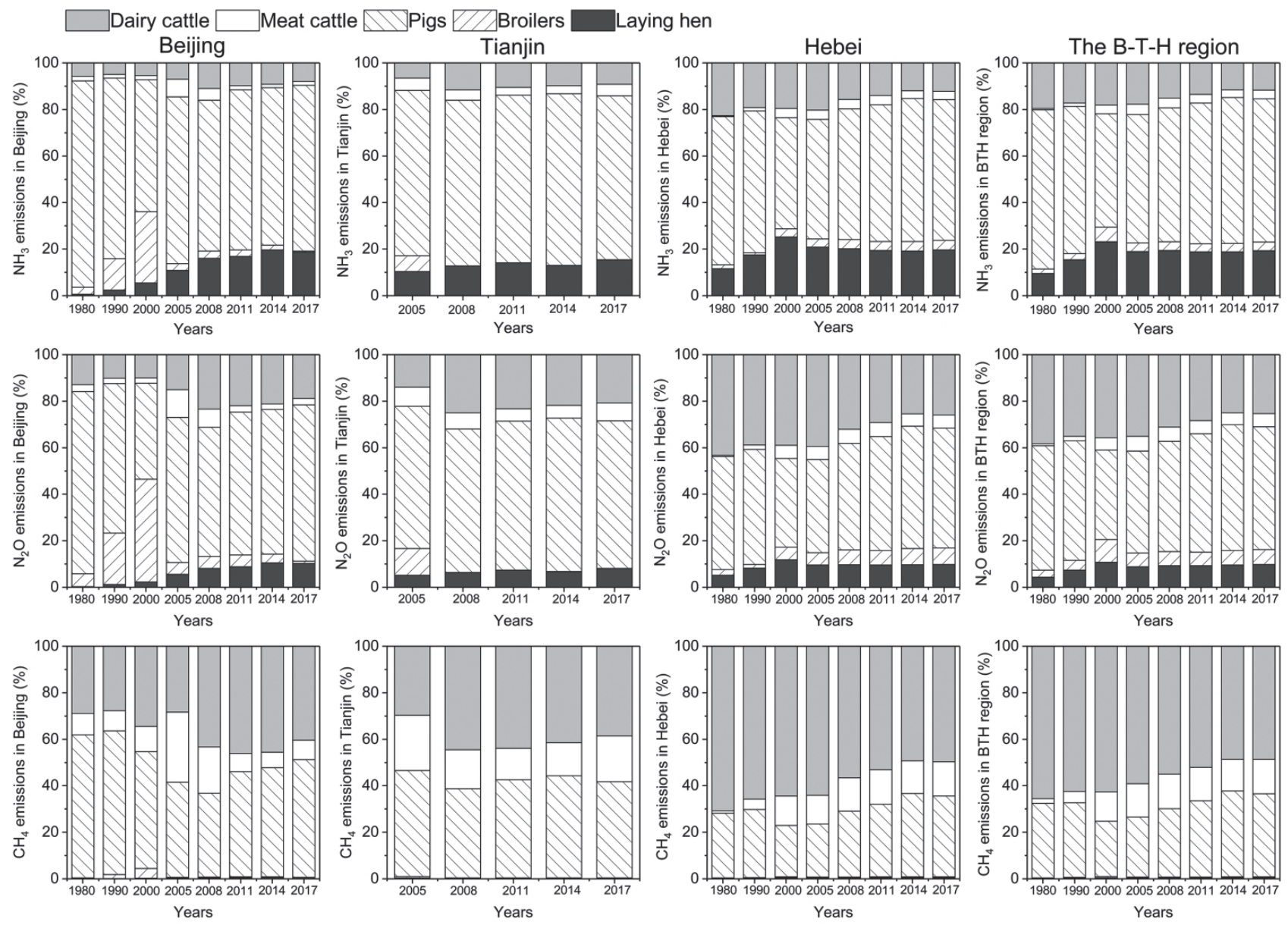

Fig. 4. The proportion of livestock-derived $\mathrm{NH}_{3}, \mathrm{~N}_{2} \mathrm{O}$ and $\mathrm{CH}_{4}$ emissions in Beijing, Tianjin, Hebei and the Beijing-Tianjin-Hebei region. 
the farming enterprises moved from the central urban area to the suburbs in Beijing.

\section{Temporal Emissions of $\mathrm{NH}_{3}, \mathrm{~N}_{2} \mathrm{O}$ and $\mathrm{CH}_{4}$ from Livestock Farming}

The livestock-derived emissions of $\mathrm{NH}_{3}, \mathrm{~N}_{2} \mathrm{O}$ and $\mathrm{CH}_{4}$ in the Beijing, Tianjin, Hebei and whole B-T-H region had similar patterns over the past 40 years (Fig. 3). They all experienced four development stages (1978-1990: low level; 1991-1995: rapid growth; 1996-2005: reached hot moments; 2006-2018: stable at high level). The livestock-derived emissions of $\mathrm{NH}_{3}, \mathrm{~N}_{2} \mathrm{O}$ and $\mathrm{CH}_{4}$ were 813, 19 and $499 \mathrm{Gg}$ in 2017, respectively. The Hebei Province accounted for the largest proportion of $\mathrm{NH}_{3}, \mathrm{~N}_{2} \mathrm{O}$, and $\mathrm{CH}_{4}$ emissions (80.3\%-95.4\%), especially in 1995. In contrast, the proportions of Beijing and Tianjin Municipality constantly decreased (Fig. 3).

The $\mathrm{NH}_{3}$ and GHGs emissions of the five livestock types in the B-T-H region were dominated by the Hebei Province (Fig. 4). The contribution of broilers to total livestock in $\mathrm{NH}_{3}$ and $\mathrm{N}_{2} \mathrm{O}$ peaked in 2000 in Beijing (30.6\% and $44.1 \%$ respectively) and then gradually decreased. On the contrary, the contribution of laying hens increased year by year and reached the peak in $2014\left(19.6 \%\right.$ and $10.5 \%$ for $\mathrm{NH}_{3}$ and $\mathrm{N}_{2} \mathrm{O}$, respectively). The culture structure in other areas changed little over time. In general, the $\mathrm{NH}_{3}$ and $\mathrm{N}_{2} \mathrm{O}$ emissions of livestock (except for dairy cattle and laying hens) decreased in Beijing and Tianjin Municipality. In contrast, the proportion of meat cattle, pigs, broilers and laying hens increased in Hebei, while only dairy cattle decreased (Fig. 4). This was consistent with the overall pattern of the B-T-H region.

\section{Spatial Emissions of $\mathrm{NH}_{3}, \mathrm{~N}_{2} \mathrm{O}$ and $\mathrm{CH}_{4}$ from Livestock Farming}

The hotspots for $\mathrm{NH}_{3}$ and $\mathrm{N}_{2} \mathrm{O}$ emissions were the cities of Shijiazhuang, Tangshan and Baoding during 2008-2017 (Fig. 5). In terms of $\mathrm{CH}_{4}$ emission, the cities of Tangshan, Shijiazhuang and Chengde had the highest emissions. In contrast, the cities of Qinhuangdao, Xingtai and Beijing had the lowest average emissions during 2008-2017. In general, the areas with higher $\mathrm{NH}_{3}$ and $\mathrm{N}_{2} \mathrm{O}$ emissions were mainly located at the junction of mountain and plain, while $\mathrm{CH}_{4}$ emissions increased in the Northwest Mountainous Areas (Fig. 5).
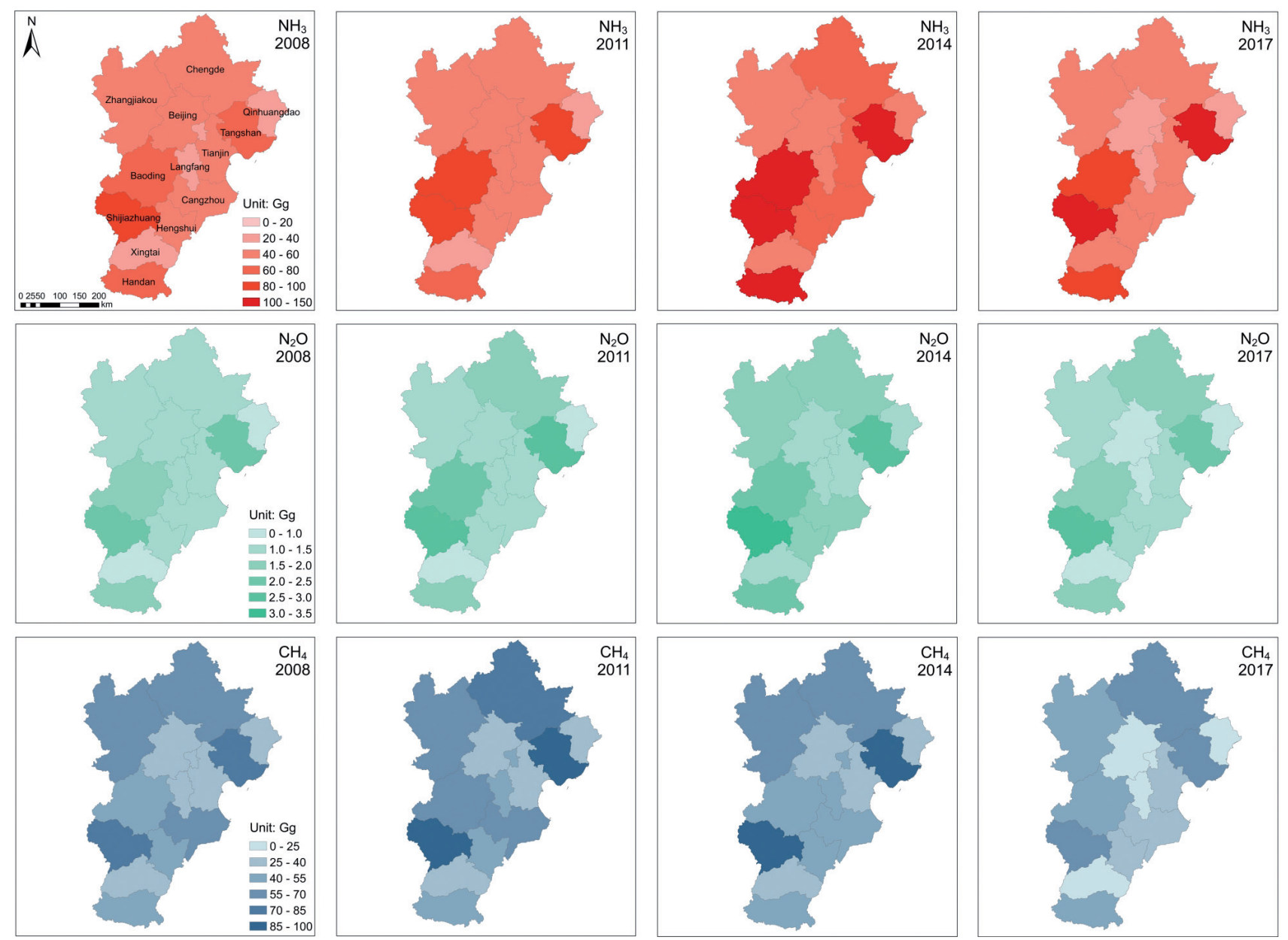

Fig. 5. Spatial emissions of $\mathrm{NH}_{3}, \mathrm{~N}_{2} \mathrm{O}$ and $\mathrm{CH}_{4}(\mathrm{Gg})$ from livestock farming in the Beijing-Tianjin-Hebei region in 2008, 2011,2014 and 2017. 
Based on the emissions per unit area, the spatial emissions of $\mathrm{NH}_{3}, \mathrm{~N}_{2} \mathrm{O}$ and $\mathrm{CH}_{4}$ changed a little bit during 2008-2017 (Fig. 6). The southeastern plain was the hotspot area, especially the cities of Shijiazhuang, Tangshan, Langfang and Handan (Fig. 6). The emissions of $\mathrm{NH}_{3}, \mathrm{~N}_{2} \mathrm{O}$ and $\mathrm{CH}_{4}$ from livestock farming in Beijing, Tianjin and surrounding cities decreased in the past decade (2008-2017).

The spatial emissions of $\mathrm{NH}_{3}, \mathrm{~N}_{2} \mathrm{O}$ and $\mathrm{CH}_{4}$ in Beijing changed little over the past 5 years (Fig. 7). The hotspots of $\mathrm{NH}_{3}$ and $\mathrm{N}_{2} \mathrm{O}$ emissions from livestock farming were mainly located in the west and northwest of Beijing, such as the town of Qianjiadian, Tanghekou and Changshaoying. In contrast, the hotspots of $\mathrm{CH}_{4}$ emission were mainly in the eastern and southeastern Beijing, such as the town of Yangzhen, Dasungezhuang and Huoxian (Fig. 7).

\section{Relationship between Livestock-Derived $\mathrm{NH}_{3}$ Emission and Atmospheric Particulate Matter Concentration}

There were linear relationships between the livestock-derived $\mathrm{NH}_{3}$ emissions and the atmospheric
$\mathrm{PM}_{25}$ and $\mathrm{PM}_{10}$ pollution in the B-T-H reign, especially for $\mathrm{PM}_{2,5}$ (Fig. 8). The livestock-derived $\mathrm{NH}_{3}$ emission per unit area explained $24 \%$ of the variation of atmospheric $\mathrm{PM}_{2.5}$ concentration (Fig. 8a) and 22\% of the variation of atmospheric $\mathrm{PM}_{10}$ concentration (Fig. 8 b).

\section{Discussion}

Spatio-Temporal Emissions of Livestock-Derived $\mathrm{NH}_{3}, \mathrm{~N}_{2} \mathrm{O}$ and $\mathrm{CH}_{4}$

From 1960 s to early 2000s, global livestock farming increased by 2 times, of which poultry and pigs increased by 3 and 1.2 times, respectively [33-34]. At the same period, the stock of cattle, pigs and poultry (laying hens and broilers) in the B-T-H region increased by $5.4,3.2$ and 12.6 times (Fig. 1), which were higher than the global level [33-34] and other countries [35-36]. Since then, the livestock of cattle, pigs, laying hens and broilers in the Beijing and Tianjin Municipality decreased sharply and moved to the suburbs. This was basically consistent with the research results of some
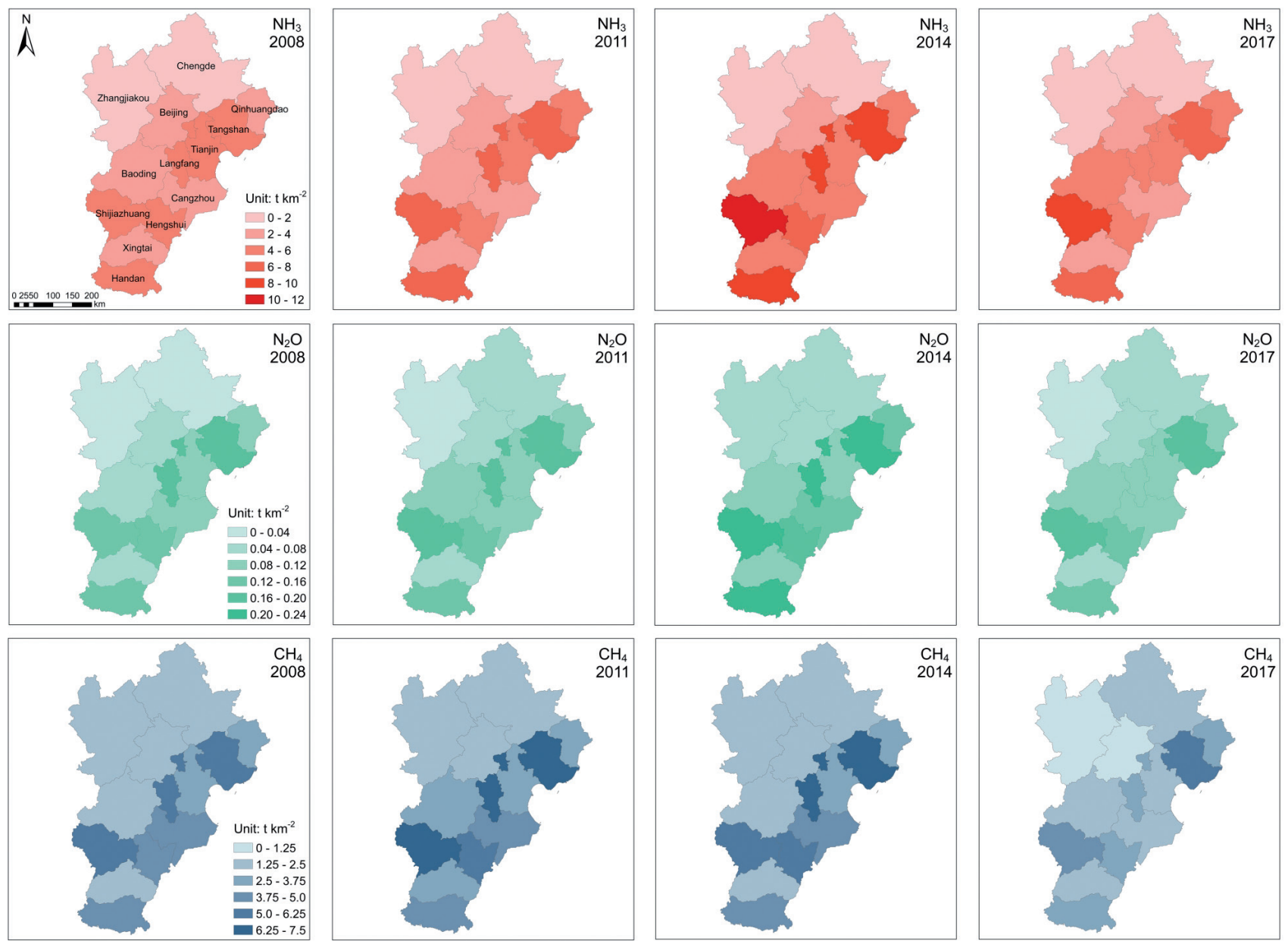

Fig. 6. Spatial emissions of livestock-derived $\mathrm{NH}_{3}, \mathrm{~N}_{2} \mathrm{O}$ and $\mathrm{CH}_{4}\left(\mathrm{Gg} \mathrm{km}^{-2}\right)$ in the Beijing-Tianjin-Hebei region in 2008, 2011, 2014 and 2017. 

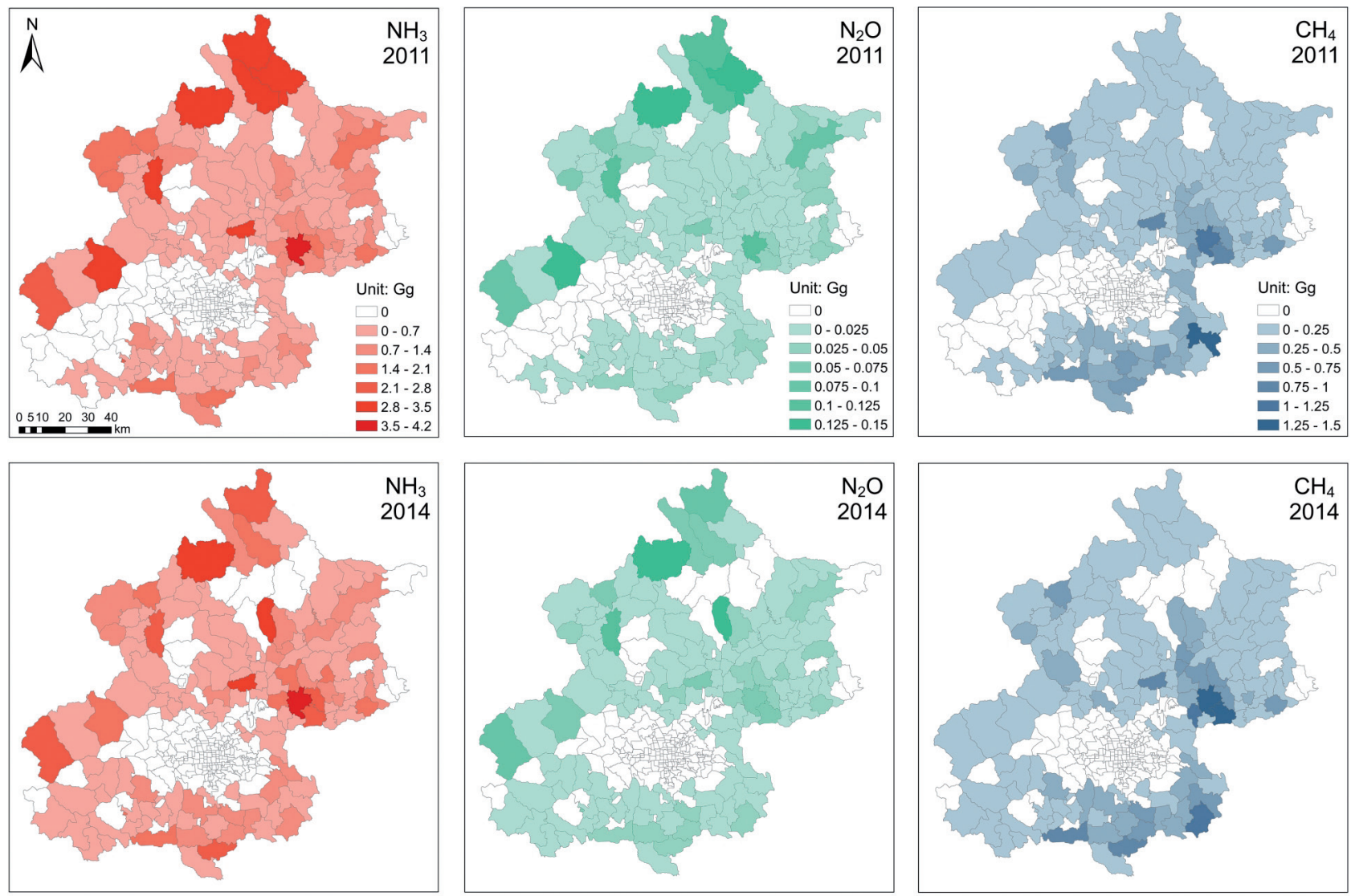

Fig. 7. Spatial emissions of livestock-derived $\mathrm{NH}_{3}, \mathrm{~N}_{2} \mathrm{O}$ and $\mathrm{CH}_{4}(\mathrm{Gg})$ in the Beijing Municipality in 2011 and 2014.

scholars $[13,20]$. This may be explained by the changes in population and livestock products increments, urbanization and green and sustainable development $[13,37]$.

The livestock-derived emissions of $\mathrm{NH}_{3}, \mathrm{~N}_{2} \mathrm{O}$ and $\mathrm{CH}_{4}$ in the B-T-H region experienced four temporal periods with peaks in 2005 (Fig. 3), which was basically consistent with the pattern of entire China [34, 38-40] and other East Asian countries [36]. Our estimation of livestock-derived $\mathrm{NH}_{3}$ emissions in the B-T-H region in $2010(759 \mathrm{Gg}$ ) and $2015(832 \mathrm{Gg}$ ) (Fig. 3) were 18\% and $13 \%$ less than that $(897 \mathrm{Gg}$ in 2010$)$ by Zhou et al. [21] and (942 Gg in 2015) by Ye et al. [3], respectively. However, our estimations of $\mathrm{NH}_{3}$ and $\mathrm{N}_{2} \mathrm{O}$ emissions in Beijing were 1.2 and 2.5 times higher than that of Liang et al. [29], which was consistent with the estimation results of Wei et al. [13]. These differences may be mainly due to different sources of data (field surveys), livestock types (such as including donkeys, mules, horses, rabbits, ducks and geese or not) and the use of slightly different emission factors.

At spatial scale, the hotspots were located in the southeast plain such as Shijiazhuang, Tangshan, Langfang and Handan (Fig. 6). This is similar to the relevant research in the B-T-H region $[21,29,41]$ and some results in South Asia [39]. Among them, cattle and pigs were the main sources of $\mathrm{NH}_{3}$ and GHGs emissions from livestock, accounting for $70-88 \%\left(\mathrm{NH}_{3}\right)$, a)
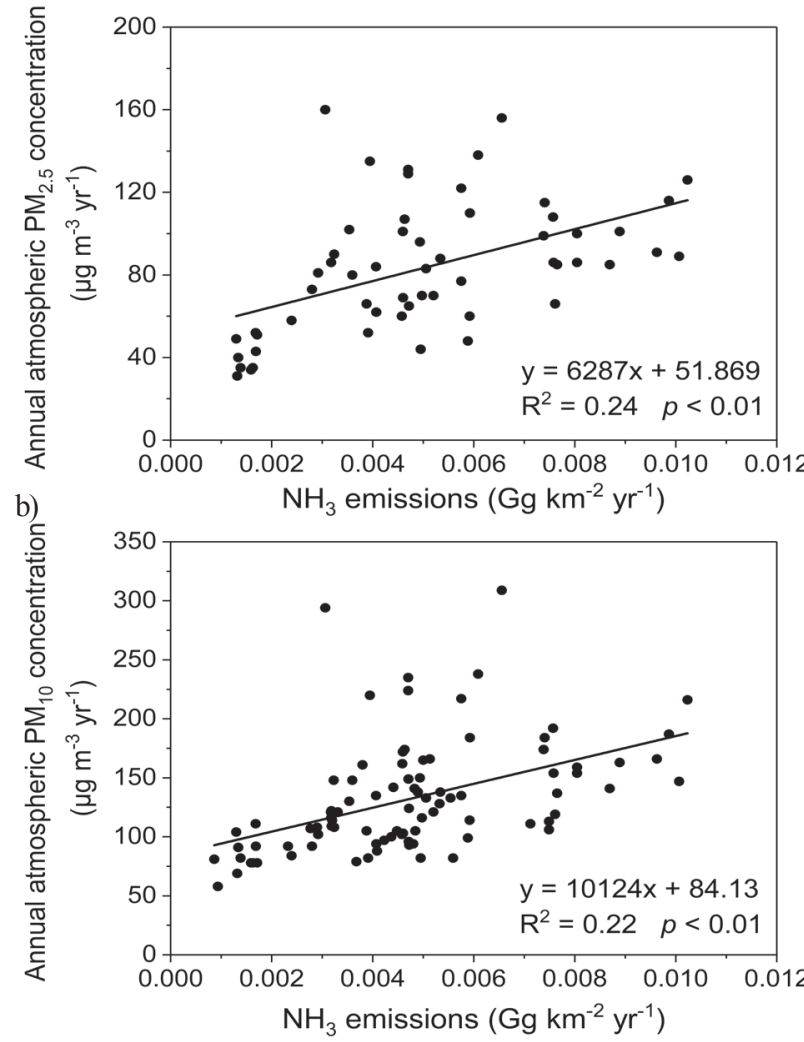

Fig. 8. Relationships between the livestock-derived $\mathrm{NH}_{3}$ emission and annual mean atmospheric particulate matter $\left(\mathrm{PM}_{2.5}\right.$ and $\mathrm{PM}_{10}$ ) concentration. 
$83-92 \%\left(\mathrm{~N}_{2} \mathrm{O}\right)$ and $99 \%\left(\mathrm{CH}_{4}\right)$ of the total emissions, respectively (Fig. 4). This is consistent with previous studies in the Red River Delta [36] and Jilin Province [42]. This spatial pattern may be related to the natural terrain advantage for southeast plain, the population and economic development degree [37].

Our research used a constant emission factor of each livestock type because of the long-term scale and unavailable dynamic emission factors. Even though this kinds of constant emission factors were from Chinese official guidelines (No. [2011]1041) and literature [31-32] thus should have reliabilities. As known, however, the actual emission factor of each specific livestock is related to the age and weight [26, 34, 43-44], geographical location [45], farming temperature [21] and feed composition [46] and other factors. Therefore, the constant emission factor of each livestock type certainly brought some uncertainty. In future research, dynamic emission factors [30, 47] should be employed, especially under the situation of developing livestock farming sector in China [48].

\section{Relationship between Livestock-Derived $\mathrm{NH}_{3}$ Emissions and Atmospheric Particulate Matter Pollution}

We found that the livestock-derived $\mathrm{NH}_{3}$ emission explained a quarter of variation of atmospheric $\mathrm{PM}_{2.5}$ pollution and $22 \%$ variation of atmospheric $\mathrm{PM}_{10}$ pollution in The B-T-H region (Fig. 8). This is reasonable because $\mathrm{NH}_{3}$ can react to form secondary particles such as ammonium nitrate $\left(\mathrm{NH}_{4} \mathrm{NO}_{3}\right)$, ammonium hydrogen sulfate $\left(\mathrm{NH}_{4} \mathrm{HSO}_{4}\right)$, ammonium sulfate $\left(\left(\mathrm{NH}_{4}\right)_{2} \mathrm{SO}_{4}\right)$ [49-50]. In addition, $\mathrm{NH}_{4}^{+}$can be combined with $\mathrm{Pb}, \mathrm{Cu}$, $\mathrm{Fe}, \mathrm{Zn}$, etc. through complexation to form secondary particles with larger diameters [51]. A substantial proportion of $\mathrm{PM}_{2.5}$ pollution was caused by aerosol formation driven by $\mathrm{NH}_{3}$ emission $[5,23]$. Therefore, we conclude that livestock-derived $\mathrm{NH}_{3}$ emission significantly affects the atmospheric particulate matter pollution in the B-T-H region.

Research conducted by the Ministry of Ecology and Environment indicated that coal consumption, industry activities, motor vehicles and dust mainly (90\%) responded for atmospheric particulate matter pollution in the B-T-H region. The Tianjin Environmental Protection Bureau believed that other emissions such as livestock farming, catering and construction contributed approximately $7 \%$ to $\mathrm{PM}_{10}$ in 2014. In addition, livestock farming contributed approximately $10 \%$ to $\mathrm{PM}_{2.5}$ in the $\mathrm{B}-\mathrm{T}-\mathrm{H}$ region $[3,28]$ and less than $4.5 \%$ to $\mathrm{PM}_{10}$ formation in Shijiazhuang [52]. Based on our result (Fig. 8), however, the influence of livestock-derived $\mathrm{NH}_{3}$ emission on atmospheric particulate matter pollution in the B-T-H region may be underestimated. Therefore, more attention needs to pay on the effect of livestock-derived $\mathrm{NH}_{3}$ emission on atmospheric particulate matter pollution in the future.
We found that the contribution of livestockderived $\mathrm{NH}_{3}$ emissions to $\mathrm{PM}_{25}$ was higher than $\mathrm{PM}_{10}$ (Fig. 8). Compared with $\mathrm{PM}_{10}, \mathrm{PM}_{2.5}$ is more controlled by reaction-generated atmospheric particles, droplets and secondary particles. In contrast, the $\mathrm{PM}_{10}$ may be more derived from relative larger size of mineral particles such as sand dust, straw burning and so on [53]. In support, the $\mathrm{NH}_{3}$ emission from pig farms increased the concentration of $\mathrm{PM}_{2.5}$, especially the amount of nitrogen-containing particles [54-55]. Therefore, it is reasonable for the better relationship between the livestock-derived $\mathrm{NH}_{3}$ emission and $\mathrm{PM}_{2.5}$, compared with that of $\mathrm{PM}_{10}$. Consequently, it is important to pay attention to the contribution of livestock-derived $\mathrm{NH}_{3}$ emissions to $\mathrm{PM}_{2.5}$ pollution.

"The European Air Pollutant Emission Inventory" [56] pointed out that intensive poultry houses (50\%) and pig houses (30\%) in Europe are important sources of atmospheric particulate matter. This indicated that livestock farming was one of the important sources of atmospheric particulate matter [12, 57]. Similarly, pigs and dairy cattle were also the main sources of $\mathrm{NH}_{3}$ and GHGs emissions from livestock farming in the B-T-H region (Fig. 4). This is consistent with the sources of GHGs from China's livestock farming [58-59]. Therefore, the reduction of $\mathrm{NH}_{3}$ and GHGs emissions should be tailored to different species of livestock (especially the pigs and cattle) and different regions.

\section{Conclusions}

Over the past 40 years, the livestock-derived emissions of $\mathrm{NH}_{3}$ and GHGs $\left(\mathrm{N}_{2} \mathrm{O}\right.$ and $\left.\mathrm{CH}_{4}\right)$ increased greatly until 2005 and subsequently remained stable in the Beijing-Tianjin-Hebei region. The southeastern plain was the hotspot, and the pig and cattle were the main sources $(>78 \%)$ of $\mathrm{NH}_{3}, \mathrm{~N}_{2} \mathrm{O}$ and $\mathrm{CH}_{4}$ emissions from livestock farming. Livestock-derived $\mathrm{NH}_{3}$ emission accounted for approximately a quarter of the variation of atmospheric $\mathrm{PM}_{2.5}$ and $\mathrm{PM}_{10}$ pollution, especially for the $\mathrm{PM}_{2.5}$. In conclusion, the livestock farming, especially the breeding of pigs and cattle, should be paid more attention in the context of atmospheric $\mathrm{PM}_{2.5}$ pollution and regional GHGs reduction.

\section{Acknowledgments}

This research was supported by the National Key Research and Development Program of China (2016YFD0800601), and the Innovation Team in Key Areas of the Tianjin Municipal Science and Technology Commission (TD12-5037).

\section{Conflict of Interest}

The authors declare no conflict of interest. 


\section{References}

1. GERBER P., STEINFELD H., HENDERSON B., MOTTE A., OPIO C., DIJKMAN J., FALCUCCI A., TEMPIO G. Tackling climate change through livestock: A global assessment of emissions and mitigation opportunities. Food and Agriculture Organization of the United Nations (FAO), Rome, 2013.

2. IPCC. Working Group III Contribution to the Fifth Assessment Report of the Intergovernmental Panel on Climate Change. Cambridge University Press, 2014.

3. YE Z.L., GUO X.R., CHENG L. Reducing PM $_{2.5}$ and secondary inorganic aerosols by agricultural ammonia emission mitigation within the Beijing-Tianjin-Hebei region, China. Atmospheric Environment. 219, 116989, 2019.

4. ZHUANG M., SHAN N., WANG Y., CARO D., WANG L. Different characteristics of greenhouse gases and ammonia emissions from conventional stored dairy cattle and swine manure in China. Science of the Total Environment. 722, 137693, 2020.

5. AN Z., HUANG R., ZHANG R., TIE X., LI G., CAO J., ZHOU W., SHI Z., HAN Y., GU Z., JI Y. Severe haze in northern China: A synergy of anthropogenic emissions and atmospheric processes. Proceedings of National Academy of Sciences of the United States of America. 116(18), 8657, 2019.

6. INAI Y., FUJITA R., MACHIDA T., MATSUEDA H., SAWA Y., TSUBOI K., KATSUMATA K., MORIMOTO S., AOKI S., NAKAZAWA T. Seasonal characteristics of trace gas transport into the extratropical upper troposphere and lower stratosphere. Atmospheric Chemistry and Physics. 19 (10), 7073, 2019.

7. FORTEMS-CHEINEY A., DUFOUR G., DUFOSSE K., COUVIDAT F., GÉNERMONT S. Do alternative inventories converge on the spatiotemporal representation of spring ammonia emissions in France? Atmospheric Chemistry and Physics. 20 (21), 13481, 2020.

8. PINDER R., ADAMS P., PANDIS S. Ammonia emission controls as a cost-effective strategy for reducing atmospheric particulate matter in the Eastern United States. Environmental Science \& Technology. 41 (2), 380, 2007.

9. EILERMAN S.J., PEISCHL J., NEUMAN J.A., RYERSON T.B., AIKIN K.C., HOLLOWAY M.W., ZONDLO M.A., GOLSTON L.M., PAN D., FLOERCHINGER C., HERNDON S. Characterization of ammonia, methane, and nitrous oxide emissions from concentrated animal feeding operations in northeastern Colorado. Environmental Science \& Technology. 50(20), 10885, 2016.

10. PORTMANN R.W., DANIEL J.S., RAVISHANKARA A.R. Stratospheric ozone depletion due to nitrous oxide: influences of other gases. Philosophical Transactions of the Royal Society B. 367 (1593), 1256, 2012.

11. CRUTZEN J.P. The role of $\mathrm{NO}$ and $\mathrm{NO}_{2}$ in the chemistry of the troposphere and stratosphere. Annual Review of Earth \& Planetary Sciences. 7 (1), 443, 1979.

12. SIDIROPOULOS C., TSILINGIRIDIS G. Trends of Livestock-related $\mathrm{NH}_{3}, \mathrm{CH}_{4}, \mathrm{~N}_{2} \mathrm{O}$ and $\mathrm{PM}$ Emissions in Greece. Water Air \& Soil Pollution. 199 (1-4), 277, 2009.

13. WEI S., BAI Z.H., CHADWICK D., HOU Y., QIN W., ZHAO Z.Q., JIANG R.F., MA L. Greenhouse gas and ammonia emissions and mitigation options from livestock production in peri-urban agriculture: Beijing - A case study. Journal of Cleaner Production. 178, 515, 2018.

14. ZHANG X., GU B., GRINSVEN H.V., SHU K.L., CHEN D. Societal benefits of halving agricultural ammonia emissions in China far exceed the abatement costs. Nature Communications. 11 (1), 1304, 2020.

15. ANEJA V.P., SCHLESINGER W.H., ERISMAN J.W. Effects of Agriculture upon the Air Quality and Climate: Research, Policy, and Regulations. Environmental Science \& Technology. 43 (12), 4234, 2009.

16. BOUWMAN A.F., LEE D.S., ASMAN W.A.H. A global high-resolution emission inventory for ammonia. Global Biogeochemical Cycles. 11 (4), 561, 1997.

17. FU C., YU G. Estimation and spatiotemporal analysis of methane emissions from agriculture in China. Environmental Management. 46 (4), 618, 2010.

18. MENG X.H., CHENG G.Q., ZHANG J.B., WANG Y.B., ZHOU H.C. Analyze on the spatialtemporal characteristics of GHG estimation of livestock's by life cycle assessment in China. China Environmental Science. 34 (08), 2167, 2014 [In Chinese with English abstract].

19. ZHU Z.P., DONG H.M., WEI S., MA J.Z., XUE P.Y. Impact of changes in livestock manure management on greenhouse gas emissions in China. Journal of AgroEnvironment Science. 39(04), 743, 2020 [In Chinese with English abstract].

20. LIU Y.X., LIU J., WU W.L. Spatiotemporal dynamics of greenhouse gases emissions from livestock and poultry in Beijing area during 1978-2009. Chinese Journal of EcoAgriculture. 21(07), 891, 2013 [In Chinese with English abstract].

21. ZHOU Y., CHENG S., LANG J., CHEN D., ZHAO B., LIU C., XU R., LI T. A comprehensive ammonia emission inventory with high-resolution and its evaluation in the Beijing-Tianjin-Hebei (BTH) region, China. Atmospheric Environment. 106, 305, 2015.

22. XU P., KOLOUTSOU-VAKAKIS S., ROOD M., LUAN S. Projections of $\mathrm{NH}_{3}$ emissions from manure generated by livestock production in China to 2030 under six mitigation scenarios. Science of the Total Environment. 607, 78, 2017.

23. XU Z.Y., LIU M.X., ZHANG M.S. High efficiency of livestock ammonia emission controls in alleviating particulate nitrate during a severe winter haze episode in northern China. Atmospheric Chemistry and Physics. 19 (8), 5605, 2019

24. MORÁN M., FERREIRA J., MARTINS H., MONTEIRO A., BORREGO C., GONZÁlEZ J.A. Ammonia agriculture emissions: From EMEP to a high resolution inventory. Atmospheric Pollution Research. 7 (5), 786, 2016.

25. XU W., ZHENG K., LIU X., MENG L., HUAITALLA R.M., SHEN J., HARTUNG E., GALLMANN E., ROELCKE M., ZHANG F. Atmospheric Pollution Research. 5 (3), 455, 2014

26. YASMEEN R., ALI Z., TYRREL S., NASIR Z.A. Estimation of particulate matter and gaseous concentrations using low-cost sensors from broiler houses. Environmental Monitoring and Assessment. 191, 470, 2019.

27. SHANG B., LIU Y., DONG H, TAO X, YAO H. Particulate matter concentrations and emissions of a fattening pig facility in northern China. Atmospheric Pollution Research. 11 (11), 1902, 2020.

28. LI X., ZHANG Q., ZHANG Y. Attribution of $\mathrm{PM}_{2.5}$ exposure in Beijing-Tianjin-Hebei region to emissions: 
implication to control strategies. Science Bulletin. 62 (13), 957, 2017.

29. LIANG L., LAL R., DU Z., WU W., MENG F. Estimation of nitrous oxide and methane emission from livestock of urban agriculture in Beijing. Agriculture, Ecosystems \& Environment. 170, 28, 2013.

30. GUO Y., WANG Y., CHEN S., ZHENG S., GUO C., XUE D., KUZYAKOV Y., WANG Z.-L. Inventory of spatiotemporal methane emissions from livestock and poultry farming in Beijing. Sustainability. 11 (14), 3858, 2019.

31. YANG Z.P. Estimation of Ammonia Emission from Livestock in China based on Mass-flow Method and Regional Comparison. Beijing University. 2008.

32. HUANG X., SONG Y., LI M., LI J., HUO Q., CAI X., ZHU T., HU M., ZHANG H. A high-resolution ammonia emission inventory in China. Global Biogeochemical Cycles. 26 (1), 1, 2012.

33. SIMS J.T., BERGSTRÖM L., BOWMAN B.T., OENEMA O. Nutrient management for intensive animal agriculture: policies and practices for sustainability. Soil Use and Management. 21, 141, 2005.

34. YU J., PENG S., CHANG J., CIAIS P., DUMAS P., LIN $\mathrm{X}$., PIAO S. Inventory of methane emissions from livestock in China from 1980 to 2013. Atmospheric Environment. 184, 69, 2018.

35. KULCU R.,'EKINCI K., EVRENDILEK F., ERTEKIN C. Long-term spatiotemporal patterns of $\mathrm{CH}_{4}$ and $\mathrm{N}_{2} \mathrm{O}$ emissions from livestock and poultry production in Turkey. Environmental Monitoring and Assessment. 167, $545,2010$.

36. TRUONG A.H., KIM M.T., NGUYEN T.T., NGUYEN N.T., NGUYEN Q.T. Methane, nitrous oxide and ammonia emissions from livestock farming in the Red River Delta, Vietnam: An inventory and projection for 2000-2030. Sustainability. 10 (10), 3826, 2018.

37. CHADWICK D., WEI J., TONG Y., YU G., SHEN Q., CHEN Q. Improving manure nutrient management towards sustainable agricultural intensification in China. Agriculture, Ecosystems and Environment. 209, 34, 2015.

38. ZHOU J.B., JIANG M.M., CHEN G.Q. Estimation of methane and nitrous oxide emission from livestock and poultry in china during 1949-2003. Energy Policy. 35 (7), 3759, 2007.

39. XU R.T., PAN S.F., CHEN J., CHEN G.S., YANG J., DANGAL S.R.S., SHEPARD J.P., TIAN H.Q. Halfcentury ammonia emissions from agricultural systems in southern Asia: Magnitude, spatiotemporal patterns, and implications for human health. GeoHealth. 2 (1), 40, 2018.

40. LOU H.Z., YANG S.T., HAO F.H., REN X.Y., ZHAO C.S., WANG Y., LEI T.J., SUN F. Evolution and Driving Forces of Non-Point Source Pollution in a Developing Megacity: Beijing as a Long-Term Case Study. Polish Journal of Environmental Studies. 29 (1), 763, 2019.

41. HU M., JIA L., WANG J., PAN Y. Spatial and temporal characteristics of particulate matter in Beijing, China using the Empirical Mode Decomposition method. Science of the Total Environment. 458, 70, 2013.

42. LI Z.Y., GAO J.T., SONG M.X. Characteristics of greenhouse gas emission from livestock and poultry farming in central Jilin Province. Jiangsu Agricultural Sciences. 46 (07), 242, 2018 (in Chinese with English abstract).

43. JANSSENS-MAENHOUT G., CRIPPA M., GUIZZARDI D., MUNTEAN M., PETRESCU A.M.R. Edgar v4.3.2 global atlas of the three major greenhouse gas emissions for the period 1970-2012. Earth System Science Data. 11 (3), 959-1002, 2019.

44. PIWOWAR, A. Low-Carbon Agriculture in Poland: Theoretical and Practical Challenges. Polish Journal of Environmental Studies. 28 (4), 2785, 2019.

45. RZEŹNIK W., MIELCAREK P. Greenhouse Gases and Ammonia Emission Factors from Livestock Buildings for Pigs and Dairy Cows. Polish Journal of Environmental Studies. 25 (5), 1813, 2016.

46. BOUWMAN A.F., HOEK K.W.V.D., EICKHOUT B., SOENARIO I. Exploring changes in world ruminant production systems. Agricultural Systems. 84 (2), 121, 2004.

47. HERRERO M., HAVLIK P., VALIN H., NOTENBAERT A., RUFINO M.C., THORNTON P.K., BLÜMMEL M., WEISS F., GRACE D., OBERSTEINER M. Biomass use, production, feed efficiencies, and greenhouse gas emissions from global livestock systems. Proceedings of National Academy of Sciences of the United States of America. 110 (52), 20888, 2013.

48. HERRERO M., HENDERSON B., HAVLÍK P., THORNTON P.K., CONANT R.T., SMITH P., WIRSENIUS S., HRISTOV A.N., GERBER P., GILL M., BUTTERBACH-BAHL K., VALIN H., GARNETT T., STEHFEST E. Greenhouse gas mitigation potentials in the livestock sector. Nature Climate Change. 6 (5), 452, 2016.

49. QIAN Y., SONG K., HU T., YING T. Environmental status of livestock and poultry sectors in China under current transformation stage. Science of the Total Environment. 622, 702, 2018.

50. HUANG R.-J., DUAN J., LI Y., CHEN Q., CHEN Y., TANG M., YANG L., NI H., LIN C., XU W., LIU Y., CHEN C., YAN Z., OVADNEVAITE J., CEBURINS D., DUSEK U., CAO J., HOFFMANN T., O'DOWD C.D. Effects of $\mathrm{NH}_{3}$ and alkaline metals on the formation of particulate sulfate and nitrate in wintertime Beijing. Science of the Total Environment. 717, 137190, 2020.

51. MENG Z., LIN W., ZHANG R., HAN Z., JIA X. Summertime ambient ammonia and its effects on ammonium aerosol in urban Beijing, China. Science of the Total Environment. 579, 1521, 2017.

52. ZHANG X., WU Y., LIU X., REIS S., JIN J., DRAGOSITS U., DAMME M.V., CLARISSE L., WHITBURN S., COHEUR P.-F., GU B. Ammonia emissions may be substantially underestimated in China. Environmental Science \& Technology. 51 (21), 12089, 2017.

53. HUA H., JIANG S., SHENG H., ZHANG Y., LIU X., ZHANG L., YUAN Z., CHEN T. A high spatial-temporal resolution emission inventory of multi-type air pollutants for Wuxi city. Journal of Cleaner Production. 229, 278, 2019.

54. GAO F. Effects of ammonia emissions from piggery on mass concentration and composition of atmospheric fine particulate matter. Shanxi University, 2018 [In Chinese with English abstract].

55. FENG T., BEI N., ZHAO S., WU J., LIU S., LI X., LIU L., WANG R., ZHANG X., TIE X., LI G. Nitrate debuts as a dominant contributor to particulate pollution in Beijing: Roles of enhanced atmospheric oxidizing capacity and decreased sulfur dioxide emission. Atmospheric Environment. 244, 117995, 2021.

56. EMEP/CORINAIR Atmospheric emission inventory guidebook, third ed., December 2007 (update 2007). https:// www.eea.europa.eu/publications/EMEPCORINAIR5. 
57. KEENER H.M., ZHAO L. A modified mass balance method for predicting $\mathrm{NH}_{3}$ emissions from manure $\mathrm{N}$ for livestock and storage facilities. Biosystems Engineering. 99 (1), 81, 2008.

58. HU X., WANG J. Estimation of livestock greenhouse gases discharge in China. Transactions of the Chinese Society of Agricultural Engineering. 26 (10), 247, 2010 [In Chinese with English abstract].
59. GUO J., QI D.S., ZHANG N., SUN L., HU R. Chinese greenhouse gas emissions from livestock: Trend and predicted peak value. Journal of Agro-Environment Science. 36 (10), 2106, 2017 [In Chinese with English abstract]. 